\title{
Phytochemical Investigation of Psoralea bituminosa L. and its Anti-Diabetic Potentials
}

\author{
Sara Al Ayoubi, Karim Raafat*, Abdalla El-Lakany, Maha Aboul-Ela
}

\section{Sara Al Ayoubi, Karim Raafat ${ }^{*}$,Abdalla El- Lakany,Maha Aboul-Ela}

Department of Pharmaceutical Sciences, Faculty of Pharmacy, Beirut Arab University, Beirut, LEBANON.

\section{Correspondence}

\section{Dr. Karim Raafat}

Department of Pharmaceutical Sciences, Faculty of Pharmacy, Beirut Arab University (BAU), Beirut, LEBANON.

Phone no : +961 1300110

E-mail: raafat@bau.edu.lb

\section{History}

- Submission Date: 29-11-2017

- Review completed: 14-03-2018;

- Accepted Date: 16-04-2018

DOI : 10.5530/pj.2018.5.143

Article Available online

http://www.phcogj.com/v10/i5

\section{Copyright}

(C) 2018 Phcog.Net. This is an openaccess article distributed under the terms of the Creative Commons Attribution 4.0 International license.

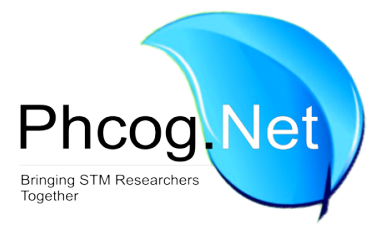

\begin{abstract}
Introduction: Psoralea bituminosa L. (Fabaceae), is a very important medicinal plant, used in traditional medicine in Europe, Asia, and America, and in Africa for, its antiseptic, antihyperglycemic and anti-oxidative potentials. The objective of this study is to investigate the potential of Psoralea bituminosa (Pbt.) in the management of diabetes and diabetic - induced thermal hyperalgesia. Moreover, this study aimed also to investigate the volatile oil constituents of Pbt. growing in Lebanon utilizing GC-MS method. Methods: Blood glucose level (BGL) was measured using gluco-meter while diabetic-induced thermal hyperplasia of Pbt. growing in Lebanon was measured using tail flick and hot plate methods. Antioxidant was measured using DPPH free radicals method. Volatile oil of fresh and dried aerial parts of Pbt. was analyzed using GC-MS. Results: The result of study conducted on Lebanese Pbt. revealed that acute anti-diabetic activity of Pbt. in the 3 extracts subjected a decrease in BGL ranging between $34 \%$ to $38.5 \%$. In subchronic anti-diabetic activity of Pbt. BGL dropped in range $19 \%$ to $44 \%$. Moreover, Pbt. extract showed $1.7 \%$ to $13.6 \%$ increase in body weight at all doses with respect to $8^{\text {th }}$ day. On the other hand, alloxan diabetic induced mice reported melioration by $63.8 \%$ to $86.3 \%$ on the $8^{\text {th }}$ week alloxan after injection in diabetic - induced thermal hyperalgesia hotplate latency method. Nevertheless, a marked improvement in tail flick latency on the $8^{\text {th }}$ week after alloxan injection by $22.7 \%$ to $48.6 \%$. Pbt. extract revealed DPPH radical decreases at $82.6 \%$ at concentration of $100 \mathrm{mg} / \mathrm{mL}$, respectively. Total flavonoid content measured of $P b t$. was $135.83 \mathrm{mg} / \mathrm{g}$ while total phenolic content showed $217.48 \mathrm{mg} / \mathrm{g}$. Conclusion: Psoralea bituminosa showed a significant effect in the management of diabetes and neuropathic pain conditions and limiting expected side-effects, which might be used as a future antidiabetic therapy.
\end{abstract}

Key words: Psoralea bituminosa, Antidiabetic, Antioxidant, Essential oil, Diabetic neuropathy.

\section{INTRODUCTION}

The Fabaceae (Leguminosae) is one of the large angiosperm family. Mainly, three subfamilies are wellknown, Papilionoideae (Faboideae) is the biggest one including about 14000 species having a characterized economically importance. ${ }^{1}$

Genus Psoralea contains important phytochemical compounds such as furanocoumarins, mainly (furo [3,2-g][1] benzopyran-7-one) which is known now a days as psoralen and angelicin which is used in skin disease treatment, pterocarpans such as bitucarpin A and bitucarpin B showing anticancer activity against colon cancer. ${ }^{2}$

P. bituminosa is a perennial herb commonly known as the pitch trefoil or Arabian pea, it is widely distributed in the Mediterranean region. ${ }^{1}$ In previous studies $P$. bituminosa reported to possess an efficient cytotoxic activity. However, Furanocoumarins presence is not the main important compound of the genus. The plant is enrich with secondary metabolites characterized by meroterpenoids and isoflavonoids. ${ }^{3}$ The extract of the aerial parts of $P$. bituminosa showed the presence of

caryophyllene, farnasene, germacene D. The presence of tricyclene and pinene was also recorded. ${ }^{4}$

Moreover, P. bituminosa volatile oil content was reported in previous studies. The major compounds found in P. bituminosa were alcohols and sesquiterpenes. ${ }^{5}$

Whereas the $\mathrm{E} \%$ value was $0.10 \mathrm{~L} / \mathrm{mg}$ every centimeter for cupric ion reducing antioxidant capacity assays. The phytochemical study of $P$. bituminosa revealed the presence of isoflavone (diazidin)and flavone (isoorientin). $\mathrm{N}$-BuOH extract of $P$. bituminosa revealed a significant anti-oxidant effect. ${ }^{3} \mathrm{~A}$ previous study was done on Algerian P. bituminosa leaves aqueous extract identifying its anti-hyperglycemic potential. Diabetes was induced in male Wistar rats by the administration of streptozotocin $(50 \mathrm{mg} / \mathrm{kg}$, i.v.). The aqueous extract was administered orally once a day for a period of 21 days. Body weight and blood glucose were determined of their lowering capacity indifferent experimental days. P. bituminosa extract had shown a significant BGL lowering effect in the oral glucose tolerance test. P. bituminosa 
aqueous extract of daily oral intake to streptozotocin-induced diabeticrats can reduce BGL after 21 days by reaching more than $31 \%$. The aqueous extract of $P$. bituminosa leaves possesses a good anti-hyperglycemic effect and is showing abright future in the therapy of Diabetes mellitus (DM). ${ }^{6}$

One of the well-known chronic diseases is DM its prevalence is increasing rapidly. DM was to be found in 219 countries and territories, moreover 382 million people is suffering from diabetes was reported in 2013. It is expected this number will increase to 592 million by 2035. DM cause metabolic disorders in carbohydrate and fat reflecting significant evidence on patient health and quality of life; hyperglycemic complications are likely to be retinopathy, cardiovascular and nephropathy damage. All over the world, diabetes is associated with long-term complications which are to be a main cause of mortality. ${ }^{6}$

DM in Lebanon was studied on 8,050 cases and divided into two groups; the first group was done on out-patients taking biological laboratory tests were the second group was evaluated on in-patient's records hospitalized. The prevalence evaluated in the hospital environment was $5.0 \%$ and the incidence varied from 1.5 to $1.7 \%$ according to the different samples; these values were similar to the international average results. ${ }^{\text {? }}$

Numerous studies have been shown that oxidative stress, mediated mainly by hyperglycemia induced generation of free radicals, contributes to the development and progression of diabetes and its complications. Diabetic neuropathy, which is one of the most frequent long-term complications of diabetes mellitus, is frequently accompanied with inferior quality of life. This complication happens in about one quarter of diabetic patients. Painful diabetic neuropathy is combined with symptoms and signs such as burning, tingling or lancing type of spontaneous pain, allodynia and hyperalgesia. ${ }^{8}$

Therefore, the objective of this study is to investigate the potential of Psoralea bituminosa ( $\mathrm{Pbt}$.) in the management of diabetes and diabeticinduced thermal hyperalgesia. Moreover, this study aimed also to investigate the volatile oil constituents of $\mathrm{Pbt}$. growing in Lebanon utilizing GC-MS method.

\section{MATERIALS AND METHODS}

\section{Plant material}

Fresh aerial parts of Psoralea bituminosa were collected from Felougha located in Lebanon about $35 \mathrm{~km}$ Eastof Beirut, Lebanon. They were authenticated by Prof. G. Tohme (Lebanese Research Center) and a dried specimen was deposited in the Pharmaceutical Sciences Department, Faculty of Pharmacy and Beirut Arab University (BAU).

\section{Preparation of plant extracts}

$P$. bituminosa aerial parts were separately air dried grinded using TCM grinder (TCM, China). Plants fine powder materials were separated into 3 portions one is extracted using $2500 \mathrm{ml}$ of $80 \%$ ethanol and were stirred for 3 days in their ethanol liquors, the other portion stirred in $2500 \mathrm{ml}$ ethylacetate for 3 days and the last portion was stirred in $2500 \mathrm{ml}$ hexane for 3 days. Flasks were covered with aluminum foil to prevent the light damage. The extracts were filtered twice using a porcelain funnel, using Rotavap (Buchi, Germany) the filtered extracts were well dried under vacuum at $40^{\circ} \mathrm{C}$.

\section{Gas chromatography-Mass Spectrometry analysis}

The plants were separated into three samples extracted by mean of solvent extraction through maceration into ethyl acetate, methanol, and hexane for 15 days. The extract was double filtered using a funnel and filter paper.

\section{Animals}

Male Swiss-Webster mice weighing 18-22 g of an age between 18-24 weeks were housed one week before experimentation (Faculty of Pharmacy,
Beirut Arab University (BAU). The environment composed of standard mice cages with a 12-h light/dark cycle. The temperature was $22 \pm 1^{\circ} \mathrm{C}$, animals had an open access to water and standard laboratory pellets ( $20 \%$ proteins, $5 \%$ fats, and $1 \%$ multivitamins. The mice were kept in those conditions for a 7-day period of adaptation prior to the start of the experiment. Sixteen hours before the experiments, they were fasted overnight, but permitted free access to water. All animal care and experiments were performed in accordance with animal experiment legislation and with approval of the local ethics commission. ${ }^{9}$

\section{Diabetes induction}

Alloxan (Sigma-Aldrich, Germany) was freshly prepared and dissolved in cold sterile saline $(0.9 \%)$. Diabetes was induced by i.p. injection of alloxan every 48 -h for three times at a dose of $180 \mathrm{mg} / \mathrm{kg}$. Blood samples were taken from the tail of experimental mice $72 \mathrm{~h}$ after the last alloxan injection to measure fasting glucose levels using glucose strips test meter. The mice that are considered to be diabetic and were to be used in the experiment is with blood glucose level more than $200 \mathrm{mg} / \mathrm{dL}$.

\section{Acute effect of plant extracts in alloxan-induced diabetic mice}

5 groups of diabetic mice were divided for each extract. Group I injected with vehicle only, cold sterile saline $(0.9 \%)$, i.p. and considered as control. Group II injected with glibenclamide dissolved in DMSO to be considered as reference drug (5 $\mathrm{mg} / \mathrm{kg}$, i.p.). P. bituminosa extract, dissolved in vehicle and was administered one extract at a time, at the doses of 25, 50 and $100 \mathrm{mg} / \mathrm{kg}$ i.p. to the diabetic mice of group III, IV and $\mathrm{V}$, respectively. Blood samples were taken from the tail just prior to and at 1/2, 2 and $6 \mathrm{~h}$ after dosing. Blood glucose and body weight were measured.

\section{Determination of Blood Glucose Concentration}

Blood glucose level was tested by Accu-chekActiveTM glucose strips in Accu-chekActiveTM Test Meter (Roche, USA). The glucose levels were expressed as $\mathrm{mg} / \mathrm{dL} .^{10-25}$

\section{Tail flick method}

The Ugo-Basile Tail Flick for assessment of management of diabetic neuropathy. It estimates precisely the nociceptive limit to infrared warmth stimulus on the rodent or mouse tail which can be adjusted continuously. The administrator begins the stimulus: when the mouse feels agony and flicks its tail, administrator stops the clock and switches off the light. The response time of the mouse is decided presented on a screened timer of the machine measured in sec and directly recorded. The Tail Flick mainly contains an infrared, of adjustable radiant energy concentrated on the animal tail. The mouse or rat is held in a mouse holder placed underneath beam part placing the beam in such a way that its tail, receives the I.R. energy. ${ }^{9}$

\section{Hot plate method}

A traditional hot plate, to do a quick exact screening diabetic neuropathy management. The UgoBasile Hot/Cold Plate is used to measure sensitivity to heat or cold stimulus of animals. When the mouse or animal lick its hind foot or shake, or jump, the time should be recorded. ${ }^{9}$

\section{Statistical Analysis}

All values were demonstrated as means \pm S.E.M. Statistical differences between the treatments and the controls were tested by two-way ANOVA using the "Originpro" statistic computer program. A difference in the mean values of $p<0.05$ or less was regarded to be statistically significant.

\section{Assessment of in vitro antioxidant activity Standard preparation}

Antioxidant activity of T. repens and P. bituminosa was assessed using $\mathrm{DPPH}$ free radicals, $\mathrm{L}$-ascorbic acid solution was used as a control and 
Ayoubi, et al.: Psoralea bituminosa Phytochemical and Biological Investigation

prepared by dissolving L-ascorbic acid in methanol and several dilutions was taken $(1 \mathrm{mg} / \mathrm{ml}, 10 \mathrm{mg} / \mathrm{ml}, 20 \mathrm{mg} / \mathrm{ml}, 40 \mathrm{mg} / \mathrm{ml}, 50 \mathrm{mg} / \mathrm{ml}, 80 \mathrm{mg} / \mathrm{ml}$, $100 \mathrm{mg} / \mathrm{ml}$ ). For Diphenyl-picryl-hydrazyl assay, $0.1 \mathrm{mM}$ stock solution of $\mathrm{DPPH}$ in methanol was prepared. All the chemicals, including solvents, were of analytical grade and Sigma Aldrich DPPH (1, 1-diphenyl-2-picrylhydrazyl free radical). ${ }^{26}$

\section{Colorimetric analysis}

The free-radical scavenging capacity of different extracts (Trifolium and Psoralea) aerial part were evaluated with the DPPH stable radical, by the methodology. Briefly, $4 \mathrm{mg} / \mathrm{ml}$ of DPPH in methanol was prepared and $2 \mathrm{~mL}$ of this solution was added to different extract concentrations $(1 \mathrm{mg} / \mathrm{ml}$, $10 \mathrm{mg} / \mathrm{ml}, 20 \mathrm{mg} / \mathrm{ml}, 40 \mathrm{mg} / \mathrm{ml}, 50 \mathrm{mg} / \mathrm{ml}, 80 \mathrm{mg} / \mathrm{ml}$, and $100 \mathrm{mg} / \mathrm{ml}$ ) and incubated at room temperature for $30 \mathrm{~min}$ to react. After $30 \mathrm{~min}$, the absorbance values were measured at $517 \mathrm{~nm}$ by a UV/Visible Spectrophotometer against blank. L-ascorbic acid was used as control.

The radical scavenging activity (percent inhibition) was stated as percentage of DPPH radical elimination calculated according to the following equation: Percentage Inhibition $(\%)=($ Ao-A/Ao $) \times 100$. Where Ao is the absorbance of the blank and $\mathrm{A}$ is the absorbance of reaction mixture (in the presence of sample). $\mathrm{IC}_{50}$ value was determined from the graph plotted between radical scavenging activity percentage inhibition (\%) and concentration $(\mathrm{mg} / \mathrm{ml})$ by linear regression analysis. $\mathrm{IC}_{50}$ value is the concentration of the sample required to scavenge $50 \% \mathrm{DPPH}$ free radical. The $\mathrm{IC}_{50}$ was calculated graphically using a calibration curve in the linear range by plotting the extract concentration $(1 \mathrm{mg} / \mathrm{ml}, 10 \mathrm{mg} / \mathrm{ml}$, $20 \mathrm{mg} / \mathrm{ml}, 40 \mathrm{mg} / \mathrm{ml}, 50 \mathrm{mg} / \mathrm{ml}, 80 \mathrm{mg} / \mathrm{ml}, 100 \mathrm{mg} / \mathrm{ml}$ ), vs the corresponding scavenging.

\section{Determination of total phenolic content in different extracts Preparation of standard}

The total phenolic content in plant extracts was concluded using FolinCiocalteu colorimetric method based on oxidation-reduction reaction. Several concentrations of Gallic acid solutions in methanol $(0.1,0.02$, $0.03,0.04$ and $0.05 \mathrm{mg} / \mathrm{ml}$ ) were set. In a $20 \mathrm{ml}$ test tube, $1 \mathrm{ml}$ Gallic acid of each concentration was added each in a separate test tube, $5 \mathrm{~mL}(10 \%)$ Folin-Ciocalteu reagent and $4 \mathrm{~mL} 7 \% \mathrm{Na}_{2} \mathrm{CO}_{3}$ were added to get a total volume of $10 \mathrm{ml}$. The blue colored mixture was shaken well and incubated for $30 \mathrm{~min}$ at $40^{\circ} \mathrm{C}$ in a water bath. The absorbance was measured at wavelength $760 \mathrm{~nm}$ against blank. The experiments were carried out in triplicate. The average absorbance values obtained at different concentrations of Gallic acid were expressed by plotting calibration curve. ${ }^{27}$

\section{Determination of total flavonoid content in different extracts Preparation of standard}

The total flavonoid content was determined by aluminum chloride colorimetric assay. Different concentrations of standard quercetin (2.0, $1.0,0.5$ and $0.25 \mathrm{mg} / \mathrm{mL}$ ) were prepared. $1 \mathrm{~mL}$ Quercetin of each concentration in methanol was added to $10 \mathrm{~mL}$ volumetric flask containing $4 \mathrm{~mL}$ double distilled water. At the zero time, $0.3 \mathrm{~mL} 5 \%$ sodium nitrite was added, after $5 \mathrm{~min}, 0.3 \mathrm{~mL}$ of $10 \% \mathrm{AlCl}_{3}$ was added to the mixture. At the $6 \mathrm{~min}, 2 \mathrm{~mL}$ of $1 \mathrm{M}$ potassium permanganate was added to the mixture.

Immediately, the total volume of the mixture was completed to the mark up to $10 \mathrm{~mL}$ by the addition of $2.4 \mathrm{~mL}$ double distilled water and mixed thoroughly. Absorbance of the pink color mixture was determined at 510 $\mathrm{nm}$ versus a blank containing all reagents except quercetin. The average absorbance values obtained at different concentrations of quercetin were used to plot the calibration curve. ${ }^{27}$

\section{RESULTS}

In this study, different doses and extract of the Pbt. were studied for their acute effects in alloxan-diabetic animals. Pbt. at all doses (25, 50 and 100 $\mathrm{mg} / \mathrm{kg}$ ) i.p showed a significant BGL decrease effect.Ethyl acetate extract of the aerial parts of $P$. bituminosa at different doses $(25,50,100 \mathrm{mg} / \mathrm{kg})$ showed a significant effect with respect to the control with blood glucose level dropping after $6 \mathrm{~h}$ of injection by $44.2 \%, 38.4 \%$, and $38.3 \%$ respectively from that of control after $6 \mathrm{~h}$ (Table 1).

Similarly, the acute anti-diabetic activity of the aerial parts of Pbt. hexane extract at all doses showed a drastic decrease in BGL at all doses $(25,50$ and $100 \mathrm{mg} / \mathrm{kg}$ ) with the glucose decreasing by $35.1 \%, 44 \%$, and $34.8 \%$, respectively from that of control after $6 \mathrm{~h}$ (Table 2). In the case of acute anti-diabetic activity of the aerial parts of $\mathrm{Pbt}$. of ethanol at different doses $(25,50$ and $100 \mathrm{mg} / \mathrm{kg}$ ) showed the best decrease in blood glucose level after $6 \mathrm{~h}$ with glucose level decreasing by $37.6 \%, 34.1 \%$, and $38.1 \%$, respectively from that of control (Table 3 ). Consequently, the aerial parts of Pbt. ethyl acetate extract showed to be the most effective reduction in the BGL.

In order to determine the subchroniceffects, three doses of Pbt. were administered throughout 8 days consecutively. The BGL of each animal was monitored on 1st, 3rd, 5th and 8th days after the administration of $P b t$. extract. In alloxan-induced diabetic mice, Pbt. at all doses $(25,50$, $100 \mathrm{mg} / \mathrm{kg}$ ) showed a significant BGL decrease. The aerial parts of P. bituminosa ethyl acetate extract showed a significant drop of BGL at different doses $(25,50$, and $100 \mathrm{mg} / \mathrm{kg})$ from that of diabetic control on the $8^{\text {th }}$ day $44 \%, 39.1 \%, 40.6 \%$, respectively (Table 4 ). Similarly, the aerial parts of $P$. bituminosa hexane extract had shown also a significant reduction of BGL at different doses $(25,50$ and $100 \mathrm{mg} / \mathrm{kg})$, respectively from that of diabetic control on the 8 th day $36.7 \%, 33.5 \%$, and $18.6 \%$ (Table 5). Subacute BGL of the aerial parts of $P$. bituminosa ethanol extract showed a significant drop illustrated at all doses $(25,50$ and $100 \mathrm{mg} / \mathrm{kg}) \mathrm{respec}-$ tively from that of diabetic control on the 8 th day $35.5 \%, 29.5 \%$, and $37.3 \%$ (Table 6). The aerial parts of P. bituminosa ethyl acetate extract effect results had made the highest drop in BGL compared to the other tested extracts.

Throughout the sub-chronic administration, mice treated with the aerial parts of $P$. bituminosa using different solvents for extraction and at different doses $(25,50$ and $100 \mathrm{mg} / \mathrm{kg}$ ) were also monitored for body weight change. The aerial parts of $P$. bituminosa ethyl acetate extract showed $5.2 \%, 6.4 \%$, and $7.6 \%$ increase in body weight at all doses with respect to $8^{\text {th }}$ day (Table 7 ).

Likewise, the aerial parts of $P$. bituminosa hexane extract showed an increase in body weight by $4.8 \%, 13.6 \%$ and $4.8 \%$ at doses $(25,50,100$ $\mathrm{mg} / \mathrm{kg}$ ), with respect to $8^{\text {th }}$ day (Table 8 ). Similarly, ethanolic extract of the aerial parts of $P$. bituminosa showed a significant increase in body weight by $11.3 \%, 1.8 \%$ and $1.7 \%$ at all dose with respect to $8^{\text {th }}$ day (Table 9 ).

\section{In vivo investigation of the diabetic neuropathy aerial parts of $P$. bituminosa extract}

Throughout the management of diabetic neuropathy, mice treated with the aerial parts of Pbt. using different solvents for extraction and at different doses $(25,50$ and $100 \mathrm{mg} / \mathrm{kg})$ were monitored in two ways using tail flick method and hot plate method. All the samples showed significant management of diabetic neuropathy after i.p.

On the other hand, alloxan diabetic induced mice reported melioration by $63.8 \%$ to $86.3 \%$ on the $8^{\text {th }}$-week alloxan after injection in diabetic induced thermal hyperalgesia hotplate latency method. Nevertheless, a marked improvement in tail flick latency on the $8^{\text {th }}$ week after alloxan injection by $22.7 \%$ to $48.6 \%$. 


\section{DPPH free radical scavenging activity of Pbt.}

Assay of the DPPH free radical scavenging activity of $P b t$. oil was carried out in a concentration-dependent manner. The DPPH free radical scavenging activity for Pbt. oil was compared with the antioxidant activity of ascorbic acid (AA) as a positive control and with the vehicle, methanol, as a control. Pbt. oil revealed a significant DPPH free radical scavenging activity $(p<0.5)$ in comparison to the control which proofs its antioxidant potential.

The amount of total phenol was determined using Folin-Ciocalteu reagent. Gallic acid was used as a standard compound and the total phenols were expressed as $\mathrm{mg} / \mathrm{g}$ Gallic acid equivalent using the standard curve equation: $\mathrm{y}=0.0045 \mathrm{x}, \mathrm{R}_{2}=0.995$, Where $\mathrm{y}$ is absorbance at $760 \mathrm{~nm}$ and $\mathrm{x}$ is total phenolic content of $P$. bituminosa extract expressed in $\mathrm{mg} / \mathrm{g}$. The total phenolic content was found in P. bituminosa showed only $(217.48 \mathrm{mg} / \mathrm{g})$.

On the other hand the amount of total flavonoid was determined with the quercetin. Quercetin was used as a standard compound and the total flavonoid were expressed as $\mathrm{mg} / \mathrm{g}$ quercetin equivalent using the standard curve equation: $\mathrm{y}=0.006 \mathrm{x}+0.038, \mathrm{R}_{2}=0.999$, Where $\mathrm{y}$ is absorbance at $510 \mathrm{~nm}$ and $\mathrm{x}$ is total flavonoid content in P. bituminosa extract expressed in $\mathrm{mg} / \mathrm{g}$. The total flavonoid content of P. bituminosa was (135.83 mg/g).

\section{Gas Chromatography-Mass Spectrometry analysis of $P$. bituminosa}

The GC-MS analysis of the aerial parts of the three samples of $P$. bituminosa obtained revealed that the oil is mainly composed of monoterpenes, Sesquiterpenes represented, fatty acids and esters in different percentages relatively (Table 13).

In the three samples, unsaturatedmonoterpenes were present in greateramounts than oxygenated monoterpene (Table 13). However, diterpenes were present at trace amounts. On the other hand, fatty acids and esters were present at greater content (Table13).

The investigation of the volatile constituent of $P$. bituminosa has been carried out for the first time in Lebanon. Tables above represents the presence of a wide variety of chemical classes related mainly to monoterpenes, sesquiterpenes, diterpenes, coumarins, amines and Flavones. In addition, the presence of fatty acids, esters, and hydrocarbons.

Sample 1 (Psoralea bituminosa, Dry, column) disclosed the occurrence of 18 peaks of which (3.2\%) oxygenated monoterpenes and sesquiterpenes, (3.81\%) unsaturated monoterpene and sesquiterpenes, $(37.746 \%)$ fatty acid and esters, $(30.13 \%)$ hydrocarbons, $(8.934 \%)$ Tricyclic amines and (8.43\%) flavone of the total. Major components were Imipramine (8.934\%), Hexadecanoic acid, methyl ester (34.622\%), 1-Leucine (11.536\%).

Sample 2 (Psoralea bituminosa, Dry, PE) disclosed the occurrence of 18 peaks of which (12.7\%) oxygenated monoterpenes and sesquiterpenes, (24.83\%) unsaturated monoterpene and sesquiterpenes, (1.6\%) diterpenes, (4.32\%) hydrocarbons, $(2.8 \%)$ tricyclic amines, and (13.64\%) flavone of the total. Major components were cedrene (3.901\%), d-limonene (14.902\%), 5, 7- dihydroxy-6, 8'-dimethyl-4'-methoxyflavone (11.539), quinolinediol (4.991).

Sample 3 (Psoralea bituminosa, fresh, PE) disclosed the occurrence of 60 peaks of which $(27.75 \%)$ oxygenated monoterpenes and sesquiterpenes, (35.34\%) unsaturated monoterpene and sesquiterpenes, $(0 \%)$ diterpenes, (21.6\%) hydrocarbons, (1\%) tricyclic amines, and $(2.8 \%)$ flavone of the total. Major components were Isocaryophyllene (5.296\%), Terpin hydrate $(5.819 \%), \delta$-Neoclovene $(11.623 \%)$ (Tables $10-13)$ (Figure 7 and $8)$.

\section{DISCUSSION}

All over the world, millions of people in the developing countries depend on medicinal plants as a primary source of healthcare. Around 70,000 plants species are known to be used in folk and modern medicinal systems all over the world. The international market of herbal plants is estimated to be 62 billion US \$ which is suspected to grow to 5 trillion US $\$$ by the year 2050. Owing to their biomedical properties, medicinal plants are extensively used in the management and prevention of agerelated diseases, cardiovascular ailments, DM and related complications. ${ }^{9}$ $P b t$. is an enduring Mediterranean herb species types developing in numerous zones around the world, particularly, in Lebanon. Pbt. contains compounds of wide pharmaceutical interest.

Lebanon vs. world prevalence of diabetes had shown that 415 million people have diabetes in the world and more than 35.4 million people in the MENA Region; by 2040 this will rise to 72.1 million. There were 464,200 cases of diabetes in Lebanon reported in 2015. ${ }^{10}$

Diabetes mellitus and its complications have been shown to be one of the major health concerns in Lebanon and world. Different studies have been done explaining the antioxidant effect importance on a diabetic patient by the generation of free radicals. This problem exists in around one-fourth of hyperglycemic patients. ${ }^{8}$

Diabetes mellitus risk has been increasing, which is a result of different pathological conditions such as hyperglycemia, obesity, and dyslipidemia and glucose intolerance. Diabetes mellitus is combined with different complications and are separated into macro vascular complications (coronary artery disease, peripheral arterial disease, and stroke) and micro vascular complications (diabetic nephropathy, retinopathy, and neuropathy). ${ }^{10}$

Numerous studies have been shown that oxidative stress, mediated mainly by hyperglycemia induced generation of free radicals, contributes to the development and progression of diabetes and its complications. ${ }^{11}$

Diabetic neuropathy is one of the major complications of diabetes and characterized by hyperalgesia, allodynia, and paresthesia, and it also affects the people life quality. The capacity of endogenous natural plants with medical function is very old and, for an extended period of time, plants were the primary source of medications.

No previous studies were conducted indicating the efficacy of $P$. bituminosa associated with diabetes mellitus and diabetic neuropathy in experimental animals.

Moreover, the objective of this study has included the anti-diabetic effect, and diabetic neuropathy management effects of $P b t$. aerial parts of different extracts (ethanol, ethyl acetate, and hexane extract) for the management of alloxan-induced diabetic mouse. For such assessment, we have studied body weight, and blood glucose level.

Moreover, we have also assessed diabetic neuropathy, diabetic complication condition using hot plate test and tail flick test parameters for alloxan-induced diabetic mice groups. In the connected study, medicinal plants rich in volatile oil especially $\mathrm{Pbt}$. have shown to be good candidate for management diabetes mellitus and diabetic neuropathy.

Alloxan significant increase of BGL baseline was $199.05 \pm 1.16 \mathrm{mg} / \mathrm{dl}$ to $103.19 \pm 0.74 \mathrm{mg} / \mathrm{dl}$. The acute anti-diabetic effect at different doses was represented in (Tables $1,3,5$ ).

Ethyl acetate extract of $P b t$. acute anti-diabetic effect was illustrated in Table 1 . All the results were statistically significant $(p<0.05)$. The glibenclamide was utilized as positive control and it inhibited the intense increase in blood glucose after $1 \mathrm{~h}$ of glucose loading, validating the experimental procedure.

Ethyl acetate extract of $P b t$. at different doses $(25,50,100 \mathrm{mg} / \mathrm{kg})$ showed a significant effect with respect to the control with blood glucose level dropping after $6 \mathrm{~h}$ of injection by $44.2 \%, 38.4 \%$, and $38.3 \%$ respectively. In previous studies, Algerian aqueous extract of $\mathrm{Pbt}$. leaves showed an effective BGL reduction of $31 \%$ when administered orally for 21 days to 
Table 1: Acute effect of $P$. bituminosa Aerial Parts (Pbt) EtAc Extract on Blood Glucose.

\begin{tabular}{cccccc}
\hline Group & $\begin{array}{c}\text { Dose } \\
(\mathrm{mg} / \mathrm{kg})\end{array}$ & \multicolumn{4}{c}{ Mean blood glucose concentration \pm S.E.M. (mg/dL) } \\
\hline & & $0 \mathrm{hr}$ & $0.5 \mathrm{hr}$ & $2 \mathrm{hr}$ & $6 \mathrm{hr}$ \\
\hline Control & - & $110.67 \pm 2.17$ & $117.67 \pm .078$ & $106.29 \pm 0.86$ & $103.19 \pm 0.74$ \\
Diabetic control & - & $214.86 \pm 2.03$ & $221.38 \pm 2.69$ & $208.67 \pm 3.43$ & $199.05 \pm 1.16$ \\
Glibenclamide & 5 & $214.29 \pm 2.95$ & $221.90 \pm 5.49$ & $119.57 \pm 7.59$ & $175.43 \pm 4.47$ \\
Pbt (EtAc) & 25 & $187.75 \pm 1.38$ & $174.25 \pm 1.48$ & $157.00 \pm 1.00$ & $111.00 \pm 2.46^{*}$ \\
Pbt (EtAc) & 50 & $228.54 \pm 2.04$ & $221.08 \pm 2.28$ & $180.42 \pm 1.84$ & $122.71 \pm 4.03^{*}$ \\
Pbt (EtAc) & 100 & $174.08 \pm 3.94$ & $188.13 \pm 1.38$ & $147.87 \pm 3.01$ & $122.68 \pm 1.05^{*}$ \\
\hline
\end{tabular}

S.E.M.: standard error mean

${ }^{*} P<0.05$ significant from the control animals.

Table 2: Subchronic Effect of Psoralea bituminosa Aerial Parts (Pbt) EtAc Extract on Blood Glucose.

\begin{tabular}{cccccc}
\hline Group & Dose $(\mathrm{mg} / \mathrm{kg})$ & \multicolumn{3}{c}{ Mean blood glucose concentration \pm S.E.M. $(\mathrm{mg} / \mathrm{dL})$} \\
\hline & & $1^{\text {st }}$ day & $3^{\text {rd }}$ day & $5^{\text {th }}$ day & $\mathbf{8}^{\text {th }}$ day \\
\hline Control & - & $107.5 \pm 1.63$ & $114.08 \pm 3.11$ & $108.5 \pm 3.64$ & $114.75 \pm 3.56$ \\
Diabetic control & - & $212 \pm 2.54$ & $210.03 \pm 4.74$ & $212.67 \pm 6.56$ & $218.67 \pm 3.46$ \\
Glibenclamide & 5 & $199.67 \pm 11.12$ & $209 \pm 4.06$ & $200 \pm 5.58$ & $203.58 \pm 6.35$ \\
Pbt (EtAc) & 25 & $164.75 \pm 27.70$ & $168.83 \pm 0.22$ & $135.92 \pm 29.42$ & $122.5 \pm 25.25^{*}$ \\
Pbt (EtAc) & 50 & $207.08 \pm 4.76$ & $198.33 \pm 0.92$ & $149.58 \pm 2.71$ & $133.08 \pm 1.82^{*}$ \\
Pbt (EtAc) & 100 & $157.42 \pm 9.85$ & $155.67 \pm 14.98$ & $169.08 \pm 3.83$ & $129.75 \pm 7.63^{*}$ \\
\hline
\end{tabular}

S.E.M.: standard error mean

${ }^{*} P<0.05$ significant from the control animals.

Table 3:Acute Effect of Psoralea bituminosa Aerial parts (Pbt) Hexane Extract on Blood Glucose.

\begin{tabular}{cccccc}
\hline Group & $\begin{array}{c}\text { Dose } \\
(\mathrm{mg} / \\
\mathrm{kg})\end{array}$ & \multicolumn{5}{c}{ Mean blood glucose concentration \pm S.E.M. (mg/dL) } \\
& & $0 \mathrm{hr}$ & $0.5 \mathrm{hr}$ & $2 \mathrm{hr}$ & $6 \mathrm{hr}$ \\
\hline Control & - & $110.67 \pm 2.17$ & $117.67 \pm .078$ & $106.29 \pm 0.86$ & $103.19 \pm 0.74$ \\
Diabetic control & - & $214.86 \pm 2.03$ & $221.38 \pm 2.69$ & $208.67 \pm 3.43$ & $199.05 \pm 1.16$ \\
Glibenclamide & 5 & $214.29 \pm 2.95$ & $221.90 \pm 5.4$ & $119.57 \pm 7.59$ & $100.43 \pm 4.47$ \\
Pbt (Hexane) & 25 & $162.25 \pm 2.52$ & $169.08 \pm 0.86$ & $147.50 \pm 0.85$ & $129.25 \pm 0.66^{*}$ \\
Pbt (Hexane) & 50 & $203 \pm 8.25$ & $164.96 \pm 2.82$ & $140.13 \pm 2.46$ & $111.38 \pm 2.67^{*}$ \\
Pbt (Hexane) & 100 & $204.79 \pm 7.87$ & $222.83 \pm 8.17$ & $181.71 \pm 11.38$ & $129.79 \pm 4.23^{*}$ \\
\hline
\end{tabular}

S.E.M.: standard error mean

${ }^{*} P<0.05$ significant from the control animals.

Table 4: Subchronic Effect of Psoralea bituminosa Aerial Parts (Pbt) Hexane Extract on Blood Glucose.

\begin{tabular}{cccccc}
\hline Group & $\begin{array}{c}\text { Dose } \\
(\mathrm{mg} / \mathrm{kg})\end{array}$ & \multicolumn{4}{c}{ Mean blood glucose concentration \pm S.E.M. $(\mathrm{mg} / \mathrm{dL})$} \\
\hline & & $1^{\text {st }}$ day & $3^{\text {rd }}$ day & $5^{\text {th }}$ day & $8^{\text {th }}$ day \\
\hline Control & - & $107.5 \pm 1.63$ & $114.08 \pm 3.11$ & $108.5 \pm 3.64$ & $114.75 \pm 3.56$ \\
Diabetic control & - & $212 \pm 2.54$ & $210.03 \pm 4.74$ & $212.67 \pm 6.56$ & $218.67 \pm 3.46$ \\
Glibenclamide & 5 & $199.67 \pm 11.12$ & $209 . \pm 4.06$ & $200 \pm 5.58$ & $183.58 \pm 6.35$ \\
Pbt (Hexane) & 25 & $148.5 \pm 1.77$ & $147.08 \pm 2.10$ & $168.67 \pm 1.72$ & $138.42 \pm 0.71^{*}$ \\
Pbt (Hexane) & 50 & $163.17 \pm 7.14$ & $136.42 \pm 2.76$ & $146.92 \pm 9.77$ & $145.42 \pm 4.24^{*}$ \\
Pbt (Hexane) & 100 & $200.97 \pm 17.11$ & $181.92 \pm 13.91$ & $183.31 \pm 7.83$ & $177.95 \pm 5.38^{*}$ \\
\hline
\end{tabular}

S.E.M.: standard error mean

${ }^{*} P<0.05$ significant from the control animals. 
Ayoubi, et al.: Psoralea bituminosa Phytochemical and Biological Investigation

Table 5:Acute Effect of P. bituminosa Aerial Parts (Pbt) EtOH Extracton Blood Glucose.

\begin{tabular}{cccccc}
\hline Group & $\begin{array}{c}\text { Dose } \\
(\mathrm{mg} / \mathrm{kg})\end{array}$ & \multicolumn{4}{c}{ Mean blood glucose concentration \pm S.E.M. (mg/dL) } \\
\hline & & $0 \mathrm{hr}$ & $0.5 \mathrm{hr}$ & $\mathbf{2 ~ h r}$ & $6 \mathrm{hr}$ \\
\hline Control & - & $110.67 \pm 2.17$ & $117.67 \pm .078$ & $106.29 \pm 0.86$ & $103.19 \pm 0.74$ \\
Diabetic control & - & $214.86 \pm 2.03$ & $221.38 \pm 2.69$ & $208.67 \pm 3.43$ & $199.05 \pm 1.16$ \\
Glibenclamide & 5 & $214.29 \pm 2.95$ & $221.90 \pm 5.49$ & $119.57 \pm 7.59$ & $175.43 \pm 4.47$ \\
Pbt (EtOH) & 25 & $238.13 \pm 1.91$ & $228.63 \pm 5.85$ & $191.17 \pm 0.72$ & $124.17 \pm 1.24^{\star}$ \\
Pbt (EtOH) & 50 & $183.5 \pm 4.85$ & $205.29 \pm 4.55$ & $150.08 \pm .62$ & $131.13 \pm 2.38^{\star}$ \\
Pbt (EtOH) & 100 & $193.33 \pm 4.98$ & $204.29 \pm 3.84$ & $145.58 \pm 3.01$ & $123.25 \pm 3.00^{*}$
\end{tabular}

S.E.M.: standard error mean

${ }^{*} P<0.05$ significant from the control animals.

Table 6: Subchronic Effect of Psoralea bituminosa Aerial Parts (Pbt) EtOHExtractson Blood Glucose.

\begin{tabular}{cccccc}
\hline Group & $\begin{array}{c}\text { Dose } \\
(\mathrm{mg} / \\
\mathrm{kg})\end{array}$ & \multicolumn{5}{c}{ Mean blood glucose concentration \pm S.E.M. (mg/dL) } \\
\hline & & $1^{\text {st }}$ day & $3^{\text {rd }}$ day & $5^{\text {th }}$ day & $8^{\text {th }}$ day \\
\hline Control & - & $107.5 \pm 1.63$ & $114.08 \pm 3.11$ & $108.5 \pm 3.64$ & $114.75 \pm 3.56$ \\
Diabetic control & - & $212 \pm 2.54$ & $210.03 \pm 4.74$ & $212.67 \pm 6.56$ & $218.67 \pm 3.46$ \\
Glibenclamide & 5 & $199.67 \pm 11.12$ & $209 . \pm 4.06$ & $200 \pm 5.58$ & $183.58 \pm 6.35$ \\
Pbt (EtOH) & 25 & $214.69 \pm 1.69$ & $192.17 \pm 2.35$ & $145.53 \pm 2.91$ & $140.92 \pm 0.60^{*}$ \\
Pbt (EtOH) & 50 & $164.33 \pm 3.97$ & $181 \pm 4.57$ & $163.42 \pm 6.98$ & $154.08 \pm 13.62^{*}$ \\
Pbt (EtOH) & 100 & $234.72 \pm 25.94$ & $168.25 \pm 2.32$ & $144.75 \pm 5.06$ & $137.19 \pm 0.56^{*}$ \\
\hline
\end{tabular}

S.E.M.: standard error mean

${ }^{*} P<0.05$ significant from the control animals.

streptozocin impelled diabetic rats. ${ }^{3}$ Algerian Pbt. extract showed less anti-diabetic efficiency compared to the Lebanese Pbt. extract.

Similarly, the acute anti-diabetic activity of Pbt. hexane extract at all doses is summarized in Table 1 . The hexane extract of $P b t$. showed a drastic decrease in BGL after $6 \mathrm{~h}$ at all doses $(25,50$ and $100 \mathrm{mg} / \mathrm{kg})$ with the glucose decreasing by $35.1 \%, 44 \%$, and $34.8 \%$, respectively.

In the case of acute anti-diabetic activity of Pbt.of ethanol summarized in Table 1 at different doses $(25,50$ and $100 \mathrm{mg} / \mathrm{kg}$ ) showed the best decrease in blood glucose level after $6 \mathrm{~h}$ compared to another extract with glucose level decreasing by $37.6 \%, 34.1 \%$, and $38.1 \%$, respectively. Consequently, P. bituminosa ethyl acetate extract showed to be the most effective reduction in the BGL. In previous studies on diabetic rats, also ethanol extract of $P$. coryfolia seeds at dose of $250 \mathrm{mg} / \mathrm{kg}-1$ caused a marked reduction of $27.8 \%$ and $31.3 \%$ in glucose levels after $4 \mathrm{hr}$ of oral introduction. ${ }^{12}$

Subchronic effects of $P$. bitumonosa with different extracting solvents of the diabetic control of mice BGL were significantly higher than those of diabetic control during the experiment illustrated in Table 1. All the results were statistically significant $(p<0.05)$.

Pbt. ethyl acetate extract showed a significant drop of BGL at different doses $(25,50$, and $100 \mathrm{mg} / \mathrm{kg})$ from that of diabetic control on the 8 th day $44 \%, 39.1 \%, 40.6 \%$, respectively (Table 2 ). Similarly, $P b t$. hexane extract had shown also a significant reduction of BGL at different doses (25, 50 and $100 \mathrm{mg} / \mathrm{kg}$ ), respectively from that of diabetic control on the $8^{\text {th }}$ day $36.7 \%, 33.5 \%$, and $18.6 \%$ (Table 4). Subchronic BGL of Pbt. ethanol extract showed a significant drop illustrated at all doses $(25,50$ and 100 $\mathrm{mg} / \mathrm{kg}$ ) respectively from that of diabetic control on the $8^{\text {th }}$ day $35.5 \%$, $29.5 \%$, and $37.3 \%$ (Table 6). Pbt. ethyl acetate extract effect results had made the highest drop in BGL compared to the other tested extracts.

Throughout the sub-chronic administration, mice treated with Pbt. using different solvents for extraction and at different doses (25, 50 and $100 \mathrm{mg} / \mathrm{kg}$ ) were also monitored for body weight change. Pbt. ethyl acetate extract showed $5.2 \%, 6.4 \%$, and $7.6 \%$ increase in body weight at all doses with respect to $8^{\text {th }}$ day (Table 7).

Likewise, $\mathrm{Pbt}$. hexane extract showed an increase in body weight by $4.8 \%, 13.6 \%$ and $4.8 \%$ at doses $(25,50,100 \mathrm{mg} / \mathrm{kg})$, with respect to $8^{\text {th }}$ day (Table 7-9). Similarly, ethanolic extract of Pbt. showed a significant increase in body weight by $11.3 \%, 1.8 \%$ and $1.7 \%$ at all dose with respect to $8^{\text {th }}$ day (Table 8 ).

In previous study, P. glandulosa leaves ethanolic extract (250 and $500 \mathrm{mg} / \mathrm{kg}$ ) which is rich in glycosides, alkaloids, sugars and oils, also showed a counteracted lessening in the body weight Ethanol extract of $P$. glandulosa leaves demonstrated good anti-diabetic activity in streptozotocin affected diabetic rats, due to its antioxidant potential through the generation of free radicals. ${ }^{11}$

Thus, the most efficient $\mathrm{Pbt}$. extract in respect to animal weight hexane extract at dose $50 \mathrm{mg} / \mathrm{kg}$ was the most efficient in this part, followed by ethanolic extract at dose $25 \mathrm{mg} / \mathrm{kg}$, the by ethyl acetate extract at dose $100 \mathrm{mg} / \mathrm{kg}$. Pbt. hexane extract has shown to be more significant than ethanol and ethyl acetate extract.

After 8 weeks of induction of DM mice were tested for diabetic neuropathy. Mice that had shown positive diabetic neuropathy response were 
Ayoubi, et al.: Psoralea bituminosa Phytochemical and Biological Investigation

Table 7: Subchronic Effect of Psoralea bituminosa Aerial Parts (Pbt) EtAc Extracts on Body Weights in Alloxan- Induced Diabetic Mice.

\begin{tabular}{cccccc}
\hline Group & $\begin{array}{c}\text { Dose } \\
(\mathrm{mg} / \mathrm{kg})\end{array}$ & \multicolumn{5}{c}{ Mean body weight \pm S.E.M. $(\mathrm{gm})$} \\
\hline & & $1^{\text {st }}$ day & $3^{\text {rd }}$ day & $5^{\text {th }}$ day & $\mathbf{8}^{\text {th }}$ day \\
\hline Control & - & $32.67 \pm 0.88$ & $33.27 \pm 0.86$ & $33.57 \pm 0.77$ & $33.9 \pm 0.75$ \\
Diabetic control & - & $34.63 \pm .49$ & $35.2 \pm 0.57$ & $36.37 \pm 0.48$ & $36.25 \pm 0.58$ \\
Glibenclamide & 5 & $30.77 \pm 0.41$ & $34.97 \pm 0.28$ & $36.53 \pm 0.34$ & $38.4 \pm 0.66^{*}$ \\
Pbt (EtAc) & 25 & $34.17 \pm 0.44$ & $34.47 \pm 0.54$ & $34.6 \pm 0.44$ & $35.23 \pm 0.34^{*}$ \\
Pbt (EtAc) & 50 & $31.87 \pm 1.45$ & $31.73 \pm 1.51$ & $32.63 \pm 1.43$ & $34.80 \pm 0.31^{*}$ \\
Pbt (EtAc) & 100 & $35.0 \pm 1.53$ & $34.43 \pm 1.32$ & $32.2 \pm 0.20$ & $34.33 \pm 0.60^{*}$ \\
\hline
\end{tabular}

S.E.M.: standard error mean

${ }^{*} P<0.05$ significant from the control animals.

Table 8: Subchronic Effect of Psoralea bituminosa Aerial Parts (Pbt) Hexane Extracts on Body Weights in Alloxan- Induced Diabetic Mice.

\begin{tabular}{cccccc}
\hline Group & $\begin{array}{c}\text { Dose } \\
(\mathrm{mg} / \mathrm{kg})\end{array}$ & \multicolumn{4}{c}{ Mean body weight \pm S.E.M. (gm) } \\
\hline & & $1^{\text {st }}$ day & $3^{\text {rd }}$ day & $5^{\text {th }}$ day & $\mathbf{8}^{\text {th }}$ day \\
\hline Control & & $32.67 \pm 0.88$ & $33.27 \pm 0.86$ & $33.57 \pm 0.77$ & $33.9 \pm 0.75$ \\
Diabetic control & - & $34.63 \pm .49$ & $35.2 \pm 0.57$ & $36.37 \pm 0.48$ & $36.25 \pm 0.58$ \\
Glibenclamide & 5 & $30.77 \pm 0.41$ & $34.97 \pm 0.28$ & $36.53 \pm 0.34$ & $38.4 \pm 0.66^{*}$ \\
Pbt (Hexane) & 25 & $32.53 \pm 1.20$ & $32.67 \pm 1.45$ & $33.93 \pm 2.03$ & $35.37 \pm 1.76^{*}$ \\
Pbt (Hexane) & 50 & $33.67 \pm 2.19$ & $32.83 \pm 2.13$ & $32.60 \pm 2.8$ & $34.0 \pm 2.04^{*}$ \\
Pbt (Hexane) & 100 & $33.67 \pm 0.88$ & $33.27 \pm 0.88$ & $34.30 \pm 0.88$ & $35.40 \pm 1.15^{*}$ \\
\hline
\end{tabular}

S.E.M.: standard error mean

${ }^{*} P<0.05$ significant from the control animals.

Table 9: Subchronic Effect of Psoralea bituminosa Aerial Parts (Pbt) EtOH Extract on Body Weights in Alloxan- Induced Diabetic Mice.

\begin{tabular}{cccccc}
\hline Group & $\begin{array}{c}\text { Dose } \\
(\mathrm{mg} / \mathrm{kg})\end{array}$ & \multicolumn{5}{c}{ Mean body weight \pm S.E.M. (gm) } \\
\hline & & 1 st day & 3rd day & 5th day & 8th day \\
\hline Control & - & $32.67 \pm 0.88$ & $33.27 \pm 0.86$ & $33.57 \pm 0.77$ & $33.9 \pm 0.75$ \\
Diabetic control & - & $34.63 \pm .49$ & $35.2 \pm 0.57$ & $36.37 \pm 0.48$ & $36.25 \pm 0.58$ \\
Glibenclamide & 5 & $30.77 \pm 0.41$ & $34.97 \pm 0.28$ & $36.53 \pm 0.34$ & $38.4 \pm 0.66^{*}$ \\
Pbt (EtOH) & 25 & $32.17 \pm 1.16$ & $32.40 \pm 1.15$ & $32.87 \pm 0.91$ & $32.97 \pm 0.88^{*}$ \\
Pbt (EtOH) & 50 & $37.23 \pm 0.58$ & $35.77 \pm 0.64$ & $35.90 \pm 0.58$ & $36.50 \pm 0.58^{*}$ \\
Pbt (EtOH) & 100 & $32.90 \pm 0.59$ & $32.40 \pm 0.70$ & $35.5 \pm 1.15$ & $36.53 \pm 1.64^{*}$ \\
\hline
\end{tabular}

S.E.M.: standard error mean

${ }^{*} P<0.05$ significant from the control animals.

included in the experiment. Diabetic mice have shown sign of hyperplasia by increase in thermal latency from baseline 0.4 to $1 \mathrm{sec}$ of diabetic control in hot plate latency and from baseline 1.5 to $1.1 \mathrm{sec}$ diabetic control of tail flick latency.

Diabetic neuropathy management using Pbt. showed a decrease in peripheral nerve condition is an influential symptom for the diabetic case having peripheral neuropathy. Pbt. extracts effects were examined on the treatment of sensory function by thermal latency measurement using tail flick and hot plate tests.
Alloxan induced diabetic mice treated with $P b t$. showed a marked thermal latency improvement. Diabetic mice showed an impermanenthyperalgesia reaction in thermal tests. On the $8^{\text {th }}$ week following alloxan increase rate, $P b t$. extracts administrated at different doses $(25,50$ and $100 \mathrm{mg} / \mathrm{kg})$ showed a hot plate latency improvement compared to vehicle control (Figure 1). Treatment of alloxan- induced diabetic mice, treated with ethyl acetate Pbt. extract showed at different doses $(25,50$ and $100 \mathrm{mg} / \mathrm{kg})$ marked hot plate latency melioration by $76.1 \%, 63.8 \%$, and $77.1 \%$ on the $8^{\text {th }}$-weekalloxan after injection. Doses 25 and $100 \mathrm{mg} / \mathrm{kg}$ showed a better hot plate latency improvement than in $50 \mathrm{mg} / \mathrm{kg}$ of $\mathrm{Pbt}$. Moreover, 
Table 10: Volatile Constituents of Sample 1 (Dried Aerial Parts of Psoralea bituminosa Extracted by Methanol).

\begin{tabular}{ccc}
\hline $\mathrm{RT}^{*}$ & Name & $\%$ of total \\
\hline 4.126 & 3-Carene & $0.185 \%$ \\
4.333 & tetradecane,1-chloro & $0.150 \%$ \\
4.422 & Cyclohexasiloxane,dodecamethyl & $0.565 \%$ \\
4.817 & 1-Eicosanol & $3.124 \%$ \\
5.044 & Caryophyllene & $0.612 \%$ \\
5.121 & Aromadendrene & $0.391 \%$ \\
5.290 & a-Caryophyllene & $1.675 \%$ \\
5.405 & Copaene & $1.040 \%$ \\
5.515 & Cedrene & $1.570 \%$ \\
5.585 & -Himachalene & $0.692 \%$ \\
5.703 & 7 -hydroxy-3-[1,1-dimethylprop-2-enyl]coumarin & $0.326 \%$ \\
5.869 & Hexadecane & $4.287 \%$ \\
5.941 & Cyclodecane & $4.029 \%$ \\
6.169 & a-Cubebene & $0.746 \%$ \\
7.626 & 1-Leucine & $11.536 \%$ \\
7.865 & 3-Octadecene & $25.518 \%$ \\
8.266 & Imipramine & $8.934 \%$ \\
12.768 & Hexadecanoic acid, methyl ester & $34.622 \%$ \\
\hline
\end{tabular}

${ }^{*}$ Retention time

Table 11: Volatile constituents of sample 2 (Dried aerial parts of Psoralea bituminosa extracted by Hexane).

\begin{tabular}{|c|c|c|}
\hline $\mathrm{RT}^{*}$ & Name & $\%$ of total \\
\hline 6.866 & 2-Pyridinamine,5,5-dibromo & \\
\hline 7.903 & 7-methoxyflavone & \\
\hline 14.612 & 5,7-dihydroxy-6,8'-dimethyl-4'-methoxyflavone & \\
\hline 14.819 & Benzo[k]fluroanthene & \\
\hline 15.480 & Phytol & \\
\hline 16.242 & Epi-bicyclosesquiphellandrene & \\
\hline 17.080 & Coumarin,3-acetyl-4-difluorobroxy & \\
\hline 18.728 & Caryophyllene & \\
\hline 21.659 & Camphene & \\
\hline 29.455 & d-Limonene & \\
\hline 30.246 & 4-[Anisylideneamino]-cinammic acid & \\
\hline 32.554 & Megestrol acetate & \\
\hline 35.169 & a-Cubebene & \\
\hline 37.875 & Copaene & \\
\hline 38.117 & a-Muurolene & \\
\hline 40.339 & Epizonarene & \\
\hline 41.975 & $\beta$-Panasinsene & \\
\hline 45.171 & Neo-isolongifolene & \\
\hline 46.969 & Isoledene & \\
\hline 54.153 & $\begin{array}{c}\text { 3-[6-methoxypyridazinyl-3-amino]-1,2- } \\
\text { naphaquinone }\end{array}$ & \\
\hline 56.037 & Cedrene & \\
\hline 71.740 & $\begin{array}{l}\text { 1,6-cyclodecadiene,1-methyl-5-methylene- } \\
8 \text { [methylethyl]-[S,E,E] }\end{array}$ & \\
\hline 73.109 & Quinolinediol & \\
\hline
\end{tabular}

${ }^{*}$ Retention time
Table 12: Volatile Constituents of Sample 3 (Fresh Aerial Parts of Psoralea bituminosa Extracted by Hexane).

\begin{tabular}{|c|c|c|}
\hline $\mathrm{RT}^{*}$ & Name & $\%$ of total \\
\hline 5.030 & 1R-a-pinene & $1.683 \%$ \\
\hline 5.252 & Octane,2,3-dimethyl & $1.222 \%$ \\
\hline 5.761 & $\begin{array}{c}\text { a-d-Glufuranose,1,2,3,5-di-O-[ethylboranediyl]6-0- } \\
\text { pivalolyl }\end{array}$ & $1.618 \%$ \\
\hline 5.829 & Coumarin,5,6,7,8-tetrafluoro-4-hydroxy-3[liminoethyl] & $0.914 \%$ \\
\hline 6.097 & $\begin{array}{l}\text { 2,6,10-dodecatriene,1-[benzyloxy]-7,11-dimethyl-5- } \\
\text { (phenylthiourea)] }\end{array}$ & $1.066 \%$ \\
\hline 6.164 & Sambucoin & $1.313 \%$ \\
\hline 6.368 & n-Methane, $[1 \mathrm{~s}, 3 \mathrm{r}]-[+]-$ & $1.935 \%$ \\
\hline 6.449 & 7-Tetradecanol & $1.827 \%$ \\
\hline 6.831 & Terpin hydrate & $5.819 \%$ \\
\hline 7.536 & Decane,4-methyl & $1.996 \%$ \\
\hline 7.758 & Cyclohexane,butyl- & $1.847 \%$ \\
\hline 10.242 & $\mathrm{~N}$-acrylonitrylaziridine & $2.614 \%$ \\
\hline 23.378 & Isocaryophyllene & $15.296 \%$ \\
\hline 24.084 & cis- $a$-bisabolene & $0.946 \%$ \\
\hline 24.788 & a-Caryophyllene & $3.052 \%$ \\
\hline 25.092 & Humulen-[V1] & $1.034 \%$ \\
\hline 25.956 & $\delta$-Neoclovene & $11.623 \%$ \\
\hline 33.207 & a-Muurolene & $1.563 \%$ \\
\hline 34.923 & Caryophyllene-[1] & $1.283 \%$ \\
\hline 38.226 & a-Farnesene & $0.665 \%$ \\
\hline 40.546 & Cedrene & $2.415 \%$ \\
\hline 40.621 & a-Cubebene & $1.547 \%$ \\
\hline 40.710 & Di-epi- $a$-cederene & $10.875 \%$ \\
\hline 40.775 & Mentha-4,8-diene, $[1 \mathrm{~s}, 3 \mathrm{~s}]-[+]$ & $1.729 \%$ \\
\hline 40.844 & Forrecene & $1.163 \%$ \\
\hline 40.909 & Dehydrodiamantane & $1.037 \%$ \\
\hline
\end{tabular}

${ }^{*}$ Retention time

hexane extract of Pbt. at different doses $(25,50$ and $100 \mathrm{mg} / \mathrm{kg})$ revealed a marked improvement in hot plate latency on the $8^{\text {th }}$ week after alloxan injection by $86.3 \%, 85.2 \%$, and $83.7 \%$ respectively compared to vehicle (Figure 2). Where dose $25 \mathrm{mg} / \mathrm{kg}$ showed the best improvement with respect to the other doses. On the other hand, the results of ethanolic extract of aerial parts of Pbt. revealing a significant improvement in hot plate latency on the $8^{\text {th }}$ week after alloxan injection by $84.1 \%, 84.9 \%$ and $84.5 \%$ at doses $(25,50$ and $100 \mathrm{mg} / \mathrm{kg})$ respectively compared to vehicle control (Figure 3).

In this extract no major difference in the efficiency between the three doses. Moreover, in previous studies on Hordeum spontaneum (HS) the $8^{\text {th }}$ week after alloxan injection, treatment with all doses $(12.5,25$ and $50 \mathrm{mg} / \mathrm{kg}$ ), hot-plate latency markedly improved by $9.6,18.7$ and $25.0 \%{ }^{8}$ but was less effective than Pbt. extract.

Nevertheless, after alloxan injection on the $8^{\text {th }}$ week, treatment with $P b t$. different extracts at different doses disclosed an improvement in tail flick latency compared to vehicle treated mice.

Where ethyl acetate extract of Pbt. at all doses $(25,50$ and $100 \mathrm{mg} / \mathrm{kg})$ with marked improvement of tail flick latency by $42.5 \%, 28.9 \%$, and $45.1 \%$, respectively compared to vehicle on $8^{\text {th }}$ week after alloxan injec- 
Table 13: Variation of Volatile Constituents of Psoralea bituminosa According to the Physical State and Method of Extraction.

\begin{tabular}{|c|c|c|c|}
\hline Plant species & \multicolumn{3}{|c|}{ Psoralea bituminosae } \\
\hline Plant location & \multicolumn{3}{|c|}{ Falougha } \\
\hline Physical state & Dry & Dry & Fresh \\
\hline Method of extraction & Column & $\begin{array}{l}\text { Petroleum } \\
\text { ether }\end{array}$ & $\begin{array}{l}\text { Petroleum } \\
\text { ether }\end{array}$ \\
\hline $\begin{array}{l}\text { Sample No./ } \\
\text { Chemical class }\end{array}$ & 1 & 2 & 3 \\
\hline $\begin{array}{l}\text { Oxygenated monoterpenes } \\
\text { and sesquiterpenes }\end{array}$ & $3.2 \%$ & $12.7 \%$ & $27.75 \%$ \\
\hline $\begin{array}{l}\text { Unsaturated monoterpene } \\
\text { and sesquiterpenes }\end{array}$ & $3.81 \%$ & $24.83 \%$ & $35.34 \%$ \\
\hline Diterpenes & -- & $1.60 \%$ & -- \\
\hline Fatty acid and esters & $37.746 \%$ & -- & -- \\
\hline Hydrocarbons & $30.131 \%$ & $4.32 \%$ & $21.6 \%$ \\
\hline Tricyclic Amines & $8.934 \%$ & $2.8 \%$ & $1 \%$ \\
\hline Flavone & -- & $13.64 \%$ & $2.8 \%$ \\
\hline
\end{tabular}

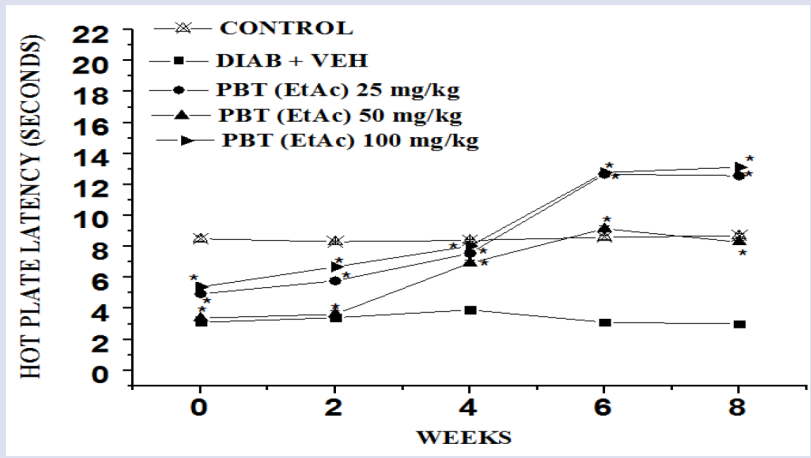

Figure 1: Effect of $P$. bituminosa aerial parts (Pbt) EtAc Extract on the Hot Plate Latency in Alloxan-Induced Diabetic Mice. Data are expressed in mean \pm S.E.M. "**" means $P<0.05$ compared with vehicle.

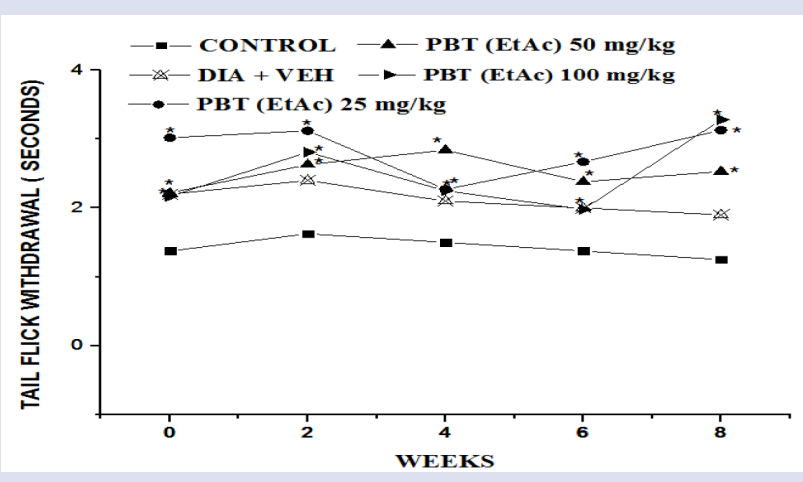

Figure 3: Effect of $P$. bituminosa aerial Parts $(P b t)$ EtOH Extract on The Hot Plate Latency in Alloxan-Induced Diabetic Mice. Data are expressed in mean \pm S.E.M. ${ }^{\text {**" }}$ means $P<0.05$ compared with vehicle.

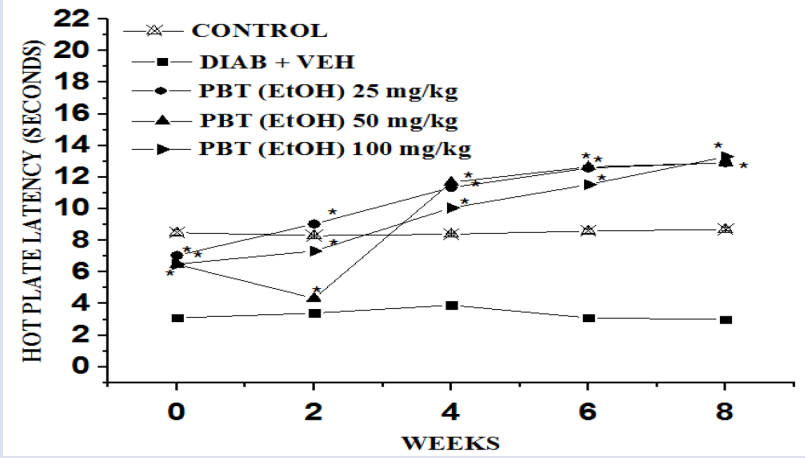

Figure 2: Effect of $P$. bituminosa aerial Parts (Pbt) Hexane Extract on the Hot Plate Latency in Alloxan-Induced Diabetic Mice. Data are expressed in mean \pm S.E.M. “*” means $P<0.05$ compared with vehicle.

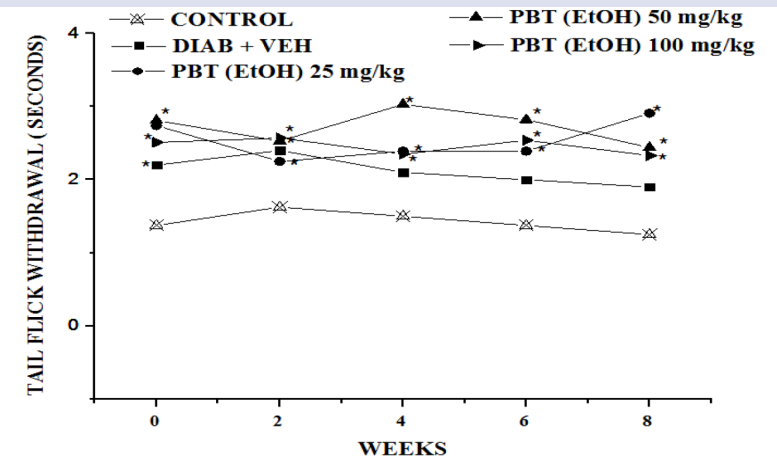

Figure 5: Effect of $P$. bituminosa aerial Parts $(P b t)$ Hexane Extract on the Tail Flick Latency in Alloxan-Induced Diabetic Mice. Data are expressed in mean \pm S.E.M. ${ }^{\text {"*” }}$ means $P<0.05$ compared with vehicle. 


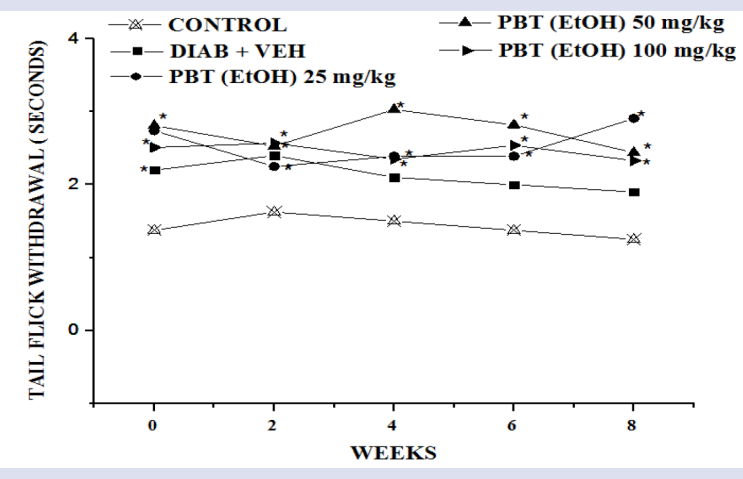

Figure 6: Effect of $P$. bituminosa aerial Parts (Pbt)EtOH Extract on the Tail Flick Latency in Alloxan-Induced Diabetic Mice.Data are expressed in mean \pm S.E.M. "**" means $P<0.05$ compared with vehicle.

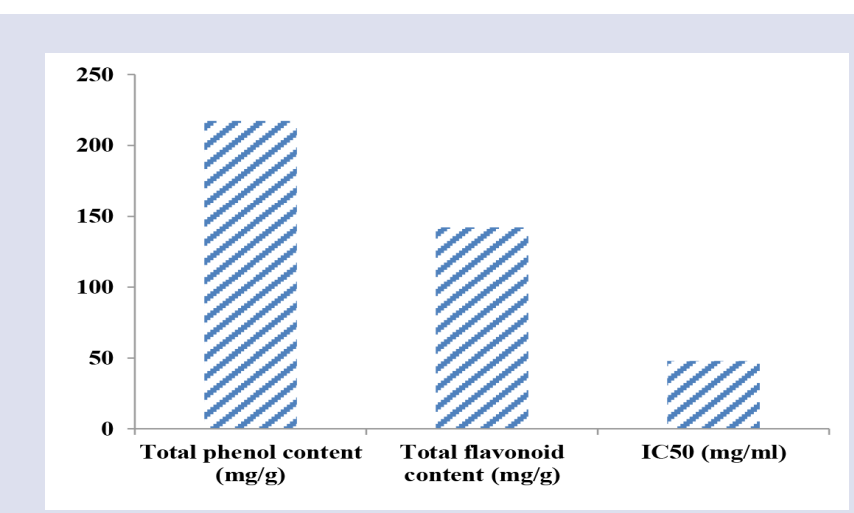

Figure 7: Total Phenolic Compounds, Total Flavonoid Compounds, and $\mathrm{IC}_{50}$ of $P$. bituminosa.

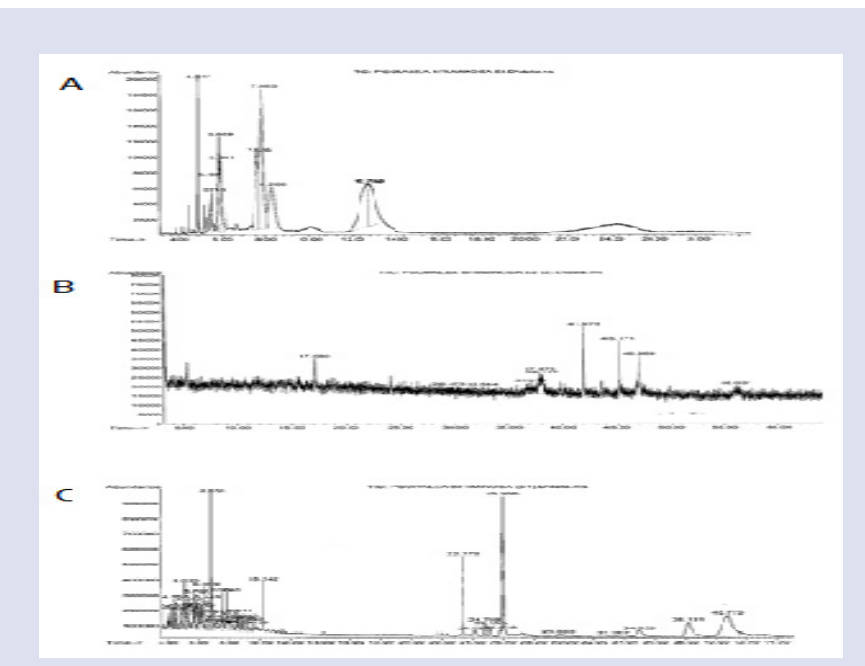

Figure 8: Investigation of Volatile Oil Constituent of Psoralea bituminosa: (A) GC-MS of Dried Aerial Parts of P. bituminosa Extracted by Methanol.(B)GC-MS of Dried Aerial Parts of $P$. bituminosa Extracted by Hexane. (C) GC-MS of Fresh Aerial Parts of Psoralea bituminosa Extracted by Ethyl Acetate. tion (Figure 4). The most efficient dose of this extract was $100 \mathrm{mg} / \mathrm{kg}$ compared to the other doses.

Moreover, hexane extract of $P b t$. at all doses $(25,50$ and $100 \mathrm{mg} / \mathrm{kg})$ with marked improvement of tail flick latency by $45.1 \%, 30.2 \%$, and $48.6 \%$, respectively compared to vehicle on $8^{\text {th }}$ week after alloxan injection (Figure 5). Dose $100 \mathrm{mg} / \mathrm{kg}$ showed the best improvement of tail flick latency like in ethyl acetate extract compared to the other two doses (25, and $50 \mathrm{mg} / \mathrm{kg}$ ).

In addition ethanol extract of Pbt. at all doses $(25,50$ and $100 \mathrm{mg} / \mathrm{kg})$ with significant improvement in tail flick latency by $38.1 \%, 26.2 \%$, and $22.7 \%$, respectively compared to vehicle on $8^{\text {th }}$ week after alloxan injection (Figure 6).

Dose $25 \mathrm{mg} / \mathrm{kg}$ showed the best tail flick improvement ethanolic extract compared to the other two doses unlike hexane and ethyl acetate extract the most efficient dose in improvement was at $100 \mathrm{mg} / \mathrm{kg}$.

In previous study of Hordeum spontaneum extract on the 8th week after alloxan injection, treatment with all doses $(12.5,25$ and $50 \mathrm{mg} / \mathrm{kg})$ of HS, showed markedly improvement of tail-flick latency by $2.3,17.3$ and $28.3 \%$ in all HS doses; ${ }^{9}$ however Pbt. was more effective in diabetic neuropathy management.

Therefore, in vitro administration of Pbt. extracts alleviated hyperalgesia in pain conditions. Our results provide clinicians promising drugs for diabetic neuropathy symptoms management. The present study indicated that indigenous Lebanese plants, explicitly, Pbt. extracts using different solvents for extraction exerted remarkable hypoglycemic activity and improved peripheral nerve function which will pave the way for management of diabetes and its related complications especially, diabetic neuropathy.

Pbt. have no reported hypoglycemic activity nor oversee diabetic neuropathy on alloxan induced diabetic mice. As to human services conveyance delivery system, a huge number of plant species and characteristic of compounds got from plants are utilized to treat diseases of irresistible origin.

Pbt. L. leaves showed an effective anti- diabetic potential in Algeria having a percentage of $31 \%$ of the antidiabetic effect. ${ }^{11}$ Moreover, $P$. corylifolia seeds of Indiawere assessed in different ways using different assays of measurement having a percentage of $27.8 \%$ to $31.3 \%$ of BGL reduction. ${ }^{12}$ Lebanese Pbt. aerial parts of our study also showed a significant BGL reduction of $18.6 \%$ to $44.2 \%$, proofing that Psoralea species can be used as a promising future anti-diabetic remedy.

The genus Psoralea (Bituminaria) is rich in phytochemical compound such as furanocoumarins, whose linear archetypal compound (furo [3, 2-g] [1] benzopyran-7-one) was named Psoralen. Paradoxically, furanocoumarins is not a main feature of the genus; it also contains Isoflavonoids and meroterpenoids. ${ }^{13}$

In recent studies the volatile fraction of Pbt. grown in Italy was isolated by steam distillation from fresh aerial parts and analyzed by GC-MS. A wide range in volatile quantitative composition was detected. Alcohols and sesquiterpenes were identified as the major compounds.

Other compounds were also detected for example hydrocarbons, phenols, furanocoumarins and monoterpenes. Aldehydes, sulphurated compounds, esters, acids and flavonoidal compounds were also identified. ${ }^{29}$ Previous studies on Psoralea corylifolia also reported the presence of several constituents like, furanocoumarins, phenyl flavonoids, aromatic terpenoids and chromenes. It is useful in inflammatory diseases, antitumor, antihyperglycemic, antidepressant, and antioxidant activity. ${ }^{14}$

The antioxidant activity of genistein and other phytoestrogens have been illustrated in several models such as protection from phorbol esterinduced singlet oxygen or peroxide formation and particularly from UV-radiation-induced oxidative damage to DNA in vitro. In mice 
dietary genistein attended to stimulate the endogenous antioxidants, SOD, GSHPx, GSHR and glutathione S-transferase, with the effects found mainly in small intestine and the skin.

Internally, the $P$. corylifolia is used in the treatment of skin problems (especially eczema and psoriasis), cancers of the breast, ovaries and lymphatic system, it is also used in chronic degenerative diseases, gout whopping cough and dry coughs. P. corylifolia extracts is indicated to possess antitumor, anti-hyperglycemic, antidepressant, and antioxidant activities due the valuable active ingredients such as flavonoids, furanocoumarins and may other substances. ${ }^{15}$

In this study, antioxidant activity of the plant extracts $\mathrm{Pbt}$. was identified using the test that is based on electron transfer (neutralization of DPPH radical). The DPPH assay method is based on the reduction of DPPH, a stable free radical. The free radical DPPH with an odd electron gives a maximum absorption at $517 \mathrm{~nm}$ (purple color).

When antioxidants react with DPPH, which is a stable free radical, it becomes paired off in the presence of a hydrogen donor (e.g., a free radical scavenging antioxidant) and is reduced to the DPPHH and as consequence the absorbance's decreased from the DPPH. Radical to the DPPH-H form, results in (yellow color) with respect to the number of electrons captured. The more the decolonization, more is the reducing ability. This test has been the most accepted model for evaluating the free radical scavenging activity of any new drug. When a solution of DPPH is mixed with that of a substance that can donate a hydrogen atom, then this gives rise to the reduced form (Diphenylpicryl hydrazine; non radical) with the loss of this violet color (although there would be expected to be a residual pale yellow color from the picryl group still present). ${ }^{16}$

$\mathrm{Pbt}$. has been reported to possess antioxidant properties. So, this study has been undertaken to evaluate their possible potential to antioxidant action by DPPH scavenging method.

In our study, $\mathrm{Pbt}$. extract were able to reduce the stable, purple-colored radical DPPH to the yellow-colored DPPH-H form. The scavenging effect of plant extract and standard (L-ascorbic acid) on the DPPH radical decreases in the following order: L-ascorbic acid $>\mathrm{Pbt}$. and it was found to be $97.4 \%$, and $82.6 \%$ at concentration of $100 \mathrm{mg} / \mathrm{mL}$, respectively.

The results were expressed as $\mathrm{IC}_{50}$. Ascorbic acid which was used as a standard showed an $\mathrm{IC}_{50}$ of $28.5 \mathrm{mg} / \mathrm{mL}$, whereas, the crude Pbt. showed antioxidant activity with $\mathrm{IC}_{50}$ value of $48.0 \mathrm{mg} / \mathrm{ml}$, respectively at $100 \mathrm{mg} / \mathrm{ml}$ concentration. Pbt. extract were not to be found more active than the standard (ascorbic acid). But still, free radical scavenging activity of aerial parts of $\mathrm{Pbt}$. extract was confirmed in the present investigation.

In the present study, Pbt. extract showed concentration dependent free radical scavenging activity. Significant results were recorded for the first time in Lebanon.

Phenolic compounds are a class of antioxidant agents which act as free radical determinate and their bioactive action may be related to their abilities to chelate metals, inhibit lipoxygenase and scavenge free radicals. The amount of total phenol was determined using Folin-Ciocalteu reagent. Gallic acid was used as a standard compound and the total phenols were expressed as $\mathrm{mg} / \mathrm{g}$ Gallic acid equivalent using the standard curve equation: $y=0.0045 \mathrm{x}, \mathrm{R}_{2}=0.995$, Where $\mathrm{y}$ is absorbance at $760 \mathrm{~nm}$ and $\mathrm{x}$ is total phenolic content of Pbt. extract expressed in $\mathrm{mg} / \mathrm{g}$. The total phenolic content was found in Pbt. showed only $(217.48 \mathrm{mg} / \mathrm{g})$.

Previous studies, on T. repens flowers extract found in (Calabria, Italy) exhibited the presence of phenolic and flavonoidal content with 79.2 mg chlorogenic acid/g extract and $19.4 \mathrm{mg}$ of quercetin equivalents/g of extract, respectively. ${ }^{17}$ That means Lebanese $P b t$. aerial parts showed a better flavonoidal and phenolic content than the flower extract of T. repens found in Italy.
The amount of total flavonoid was determined with the quercetin reagent. Quercetin was used as a standard compound and the total flavonoid were expressed as $\mathrm{mg} / \mathrm{g}$ quercetin equivalent using the standard curve equation: $\mathrm{y}=0.006 \mathrm{x}+0.038, \mathrm{R}_{2}=0.999$, Where $\mathrm{y}$ is absorbance at $510 \mathrm{~nm}$ and $\mathrm{x}$ is total flavonoid content in Pbt. extract expressed in $\mathrm{mg} / \mathrm{g}$. The total flavonoid content of Pbt. was $(135.83 \mathrm{mg} / \mathrm{g})$. The result obtained from present study showed that the extract of which contain high amount of flavonoid and phenolic compounds in different percentages, was the reason of the significant antioxidant activity present, thus can be used to explore new drugs.

All the results demonstrated that the volatile components of aerial parts $P b t$. oil varies significantly according to the physical state of the plant (fresh or dried), and the method of extraction.

Samples (1, 2, and 3) are the samples of the aerial part of Pbt. growing in Felougha in Lebanon. To compare the methods of extraction and the physical state of the plant, dry samples $(1,2)$ were considered.

In sample (1) represented low content of oxygenated monoterpenes and sesquiterpenes (3.2\%), unsaturated monoterpene and sesquiterpenes (3.81\%) with high percentage of fatty acid and esters (37.746\%), tricyclic amines $(8.934 \%)$, in comparison to sample 2 that revealed a higher content of oxygenated monoterpenes and sesquiterpenes (12.7\%), unsaturated monoterpene and sesquiterpenes (24.83\%), diterpenes (1.60\%), flavone (13.64\%) and lower content of tricyclic amines (2.8\%). Fresh sample (3) revealed a higher content than both samples $(1,2)$ of oxygenated monoterpenes and sesquiterpenes (25.75\%), unsaturated of monoterpene and sesquiterpenes (35.34\%), but revealed a lower content compared to sample (2) of tricyclic amines (1\%), and flavone (2.8\%).

$\mathrm{Pbt}$. aerial parts under investigation had been shown to be a rich source of the biological active monoterpenes, sesquiterpenes, tricyclic amines, flavones and fatty acid, esters in addition of hydrocarbons playing an important role in reducing blood glucose level and reducing pain sensation. Some phytochemical content also showed antimicrobial effects. Most of the samples of Pbt. aerial parts living around the world showed the presence of Caryophyllene, $\beta$-Farnesene, and Germacrene-D as major common compounds in different percentages. Previous study had been conducted on Pbt. aerial part growing in Italy showed the presence of major active ingredients Caryophyllene (23\%), $\beta$-Farnesene (18\%), and Germacrene-D (24\%). Another study was also evoked in India showing the presence of major compounds found in aerial part of Pbt. Caryophyllene (23\%), $\beta$-Farnesene (15\%), and Germacrene-D $(18 \%)$.

Moreover, one study was conducted on $\mathrm{Pbt}$. aerial part cultivated in Russia has shown to include Caryophyllene (21\%), $\beta$-Farnesene (13\%), and Germacrene-D (20\%) as major active compounds of the plant.

Lebanese Pbt. showed the presence of Caryophyllene in the entire sample in different percentages besidea difference is evident for Germacrene-D and $\beta$-Farnesene indicating the absence of those two compounds in our samples. On the other hand, the presence of $\alpha$-Farnesene was indicated instead, and the existence of new compounds that are not present or recorded in previous studies outside Lebanon was discovered.

Sample 2 of Pbt. aerial parts showed the presence of important compounds that play an anti-diabetic role 5, 7-dihydroxy-6, 8'-dimethyl4'-methoxyflavone (11.539\%), andD-limonene (14.902\%). The previous study conducted on Callistemon lanceolatus DC containing 5, 7-dihydroxy-6, 8-dimethyl-4'-methoxyflavone isolated during phytochemical analysis was evaluated, this flavone possessed a significant anti-diabetic effect in diabetic streptozotocin- induced rats. ${ }^{19}$ Moreover another study was conducted on D-Limonene evaluating its anti-diabetic effect, it is a monoterpene found in orange and citrus fruits like lemon and grapefruit. D-Limonene has many activities such as antioxidant, anti-carcinogenic, 
Ayoubi, et al.: Psoralea bituminosa Phytochemical and Biological Investigation

and anti-inflammatory activity. D- Limonene was given orally to be tested on streptozotocin diabetic- induced rats showing a significant effect of lowering blood glucose level and improvement in body weight. ${ }^{20}$ Sample 3 of Pbt. aerial parts contained also a bioactive compound that plays an important role in diabetic complications such as diabetic neuropathy. Caryophyllene is a bicyclic sesquiterpene it was tested in previous studies showing an anti-nociceptive analgesic effect. ${ }^{21} \mathrm{New}$ compounds were also detected in $\mathrm{Pbt}$. aerial parts possessing important pharmacological effects.

Imipramine is known in the market as Tofranil or melipramineit's a tricyclic antidepressant (TCA) of the dibenzazepine group. Its mainly used as antidepressant and for nocturnal enuresis (inability to control urination). ${ }^{22}$ Plumbane; Fluvalinate; a synthetic pyrethroid used to control varroa mites found in honey bee colonies, Perylene; polycyclic aromatic hydrocarbon a hazardous pollutant and mainly used as fluorescent lipid probe, ${ }^{23}$ 1-Leucine; is an alpha amino acid used in the liver, adipose tissue and muscle tissue in the formation of sterols, and is a major component of the subunits in ferritin, astacin, and other 'buffer' proteins. ${ }^{24}$ Terpin hydrate; an expectorant, commonly used to loosen mucus in patients presenting with acute or chronic bronchitis, and related conditions. ${ }^{25}$ Copane and Cedrene were also isolated from our samples of minor amounts as previous literature also showed the presence of these compounds in minor quantities too. Pbt. aerial parts appearing in Lebanon and other countries revealed that sesquiterpenes are the major compounds isolated from most of the plant organs.

Consequently, this study has explored the volatile components and pharmacological effect of Pbt. aerial parts for the first time in Lebanon.

\section{CONCLUSION}

In conclusion, the increase in blood glucose level will cause increase in oxidative stress and diabetic complication. There is considerable evidence that reduction of oxidative stress is a key process in the amioleration of diabetic complications. The results of $\mathrm{Pbt}$. aerial parts in amiolerating BGL and its significant antioxidant activity having to be a part of mechanism of action by with $P b t$. aerial parts decreased diabetic complication. Therefore, clinicians should take into consideration $\mathrm{Pbt}$. when trying to find treatment for acute and chronic disorders.

\section{ACKNOWLEDGEMENT}

Authors would like to thank G. Onsy for English proofreading the manuscript.

\section{CONFLICTS OF INTEREST}

There are no conflicts of interest.

\section{ABBREVIATIONS}

Pbt: Psoralea bituminosa; BGL: Blood Glucose Level; DPPH-2: 2-diphenyl-1-picrylhydrazyl, SD: Standard deviation; S.E.M: Standard error of the mean.

\section{REFERENCES}

1. Peters WS, Haffer D, Hanakam CB, Van Bel AJ, Knoblauch M. Legume phylogeny and the evolution of a unique contractile apparatus that regulates phloem transport. Am J Bot. 2010;97(5):797-808.

2. Wink M. Evolution of secondary metabolites in legume (Fabaceae). S Afr J Bot. 2013;89:164-75

3. Salima A, Nabila Z, Kamel M, Salah A, Kadour B, Farida S, Marie-Geneviève Dijoux-Franca. Phytochemical and biological activities of Bituminaria bituminosa
L. (Fabaceae). Asian Pac J Trop. Med.2014;7(1):S481-S4.

4. Zhao LH, H C, Shan Z, Xiang BG, Mei LH. Fingerprint analysis of Psoralea corylifolia by HLPC and LC-MS. J Chromatogr B. 2005;821(1):67-74.

5. Tava A, P L, Ricci M, Pagnotta M A, Russi L. Volatile compounds from leaves and flowers of Bituminaria bituminosa (L.) Stirt. (Fabaceae) from Italy. Flavour Fragr J. 2007;22(5):363-70.

6. Lemouchi R, Selles C, Medjdoub H, Tabti B. Assessment of possible efficacy of aqueous leaves extract of Psoralea bituminosa L. for anti-hyperglycaemic activity. Asian Pac J Trop. Dis. 2015;5(7):575-8.

7. Hirbli KI, Aboujaoudé JH, Ghorra FS, Barakat-el-Khoury WM. Prevalence and incidence of diabetes mellitus in Lebanon. Diabete Metab. 1990;16(6):479-83.

8. Karim R, Rima B, Maha Aboul Ela and Abdalla El-Lakany. Endogenous Lebanese Plants Treating Diabetes and Related Complications. J of Natural Products Chem and Res. 2013;1(3):112-20.

9. Karim R, Abdalla El-Lakany. Acute and subchronic in-vivo effects of Ferula hermonis $L$. and Sambucus nigra $L$. and their potential active isolates in a diabetic mouse model of neuropathic pain. Complementary and Alternative Medicine 2015;15(1):257.

10. Michael J. Fowler. Microvascular and Macrovascular Complications of Diabetes. Clinical Diabetes. 2008;26(2):77-82.

11. Kotresha D, Sandhya D. Prakash T. Hypoglycemic activity of Psoralea glandulosa on streptozocin-indecd diabetic rats. Int J of Biopharma Res. 2014;3(5).

12. Kotresha D, Sandhya D, Prakash T. Hypoglycemic activity of Psoralea glandulosa on streptozocin-indecd diabetic rats. Int J of Biopharma Res. 2014;3(5).

13. Luisa P, Cecilia N, Giovanni App, Federica B, Olov St, Mauro B. Pterocarpans from Bituminaria morisiana and Bituminaria bituminosa. Phytochemistry. 2003;64(2):595-8.

14. Khushboo P S, Jadhav V M, Kadam V J, and Sathe N S. Psoralea corylifolia Linn."Kushtanashini." Pharmacogn Rev. 2010;4(7):69-76.

15. Qiuyin C, Huachen W. Effect of dietary genistein on antioxidant enzyme in SENCAR mice. Nutrition and Cancer. 1996;25(1):1-7.

16. Somanathan S S, Ranganayakulu D, Jayaveera K N. In-vitro antioxidant activities of Asystasia gangetica leaf extract. World $\mathrm{J}$ of Phand Pharm Sc. 2015;4(2):1228-39.

17. Rosa T, Mariangela M, Filomena C, Maria CT, Marco B, Francesco M. et al. Trifolium pratense and T. repens (Leguminosae): Edible Flower Extracts as Functional Ingredients. Foods. 2015;4(3):338-48.

18. Hosamni PA, Lakshman HC, and Sandeep kumar K. Antimicrobial activity of leaf extract of Psoralea Coryfolia. Life Science Leaflets. 2012;8:35-9.

19. Nazreen S, Kaur G, Alam MM, Shafi S, Hamid H, Ali M, Alam MS. New flavones with antidiabetic activity from Callistemon lanceolatus DC. Fitoterapia. 2012;83(8):1623-7.

20. Ramakrishnan M, Ramalingam S. Antidiabetic effect of d-limonene, a monoterpene in streptozotocin-induced diabetic rats. Biomedicine and Preventive Nutrition. 2012;2(4):269-75.

21. Katsuyama S, Mizoguchi $H$, Kuwahata $H$. Involvement of peripheral cannabinoid and opioid receptors in $\beta$-caryophyllene-induced antinociception. European Journal of Pain. 2013;17(5):664-75.

22. Lepola U, Arató M, Zhu Y, Austin C. Sertraline versus imipramine treatment of the comorbid panic disorder and major depressive disorder. The Journal of Clinical Psychiatry. 2003;64(6):654-6.

23. Donaldson D M, Robertson J M, White J G. The crystal and molecular structure of perylene. Proceedings of the Royal Society A. 1953;220(1142):311-21.

24. Rosenthal J. Metabolic fate of leucine: A significant sterol precursor in adipose tissue and muscle. American Journal of Physiology Renal Physiology. 1974;226(2):411-8

25. United States Food and Drug Administration: Code of Federal Regulations. 2009;5

26. Mohammmad A, Ela MA, Raafat K, Abdalla El-L. Role of Antioxidants in the Antidiabetic Potential of Two Indigenous Lebanese Inula Species. Med Aromat. Plants. 2015;2:2167-0412.

27. Laxman $B$, Meena $R$. Isolation of quercetin from flower petals, estimation of total phenolic, total flavonoid and antioxidant activity if the different parts of Rhododendron arboretum smith. Scientific World. 2014;12(12):34-40.

28. Buchbauer G, Jirovetz L, Nikiforov A. Comparative Investigation of Essential Clover Flower Oils from Austria Using Gas Chromatography-Flame Ionization Detection, Gas Chromatography-Mass Spectrometry, and Gas Chromatography-Olfactometry.J Agric Food Chem. 1996;44(7):1827-8. 
GRAPHICAL ABSTRACT

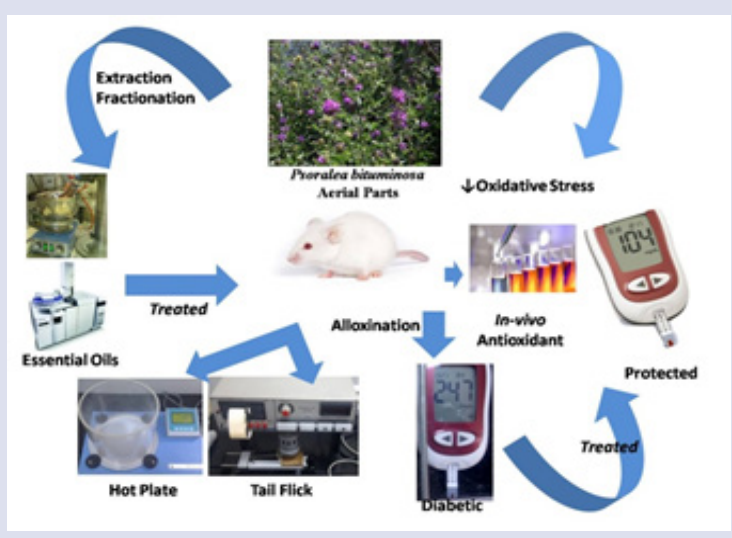

\section{SUMMARY}

The increase in blood glucose level will cause increase in oxidative stress and diabetic complications. There is considerable evidence that reduction of oxidative stress is a key process in the amioleration of diabetic complications. The results of Psoralea bituminosaaerial parts $(P b t$.) in amiolerating BGL and its significant antioxidant activity having to be a part of mechanism of action by with $P b t$. aerial parts decreased diabetic complication. Therefore, clinicians should take into consideration Pbt. when trying to find treatment for acute and chronic disorders.

\section{ABOUT AUTHORS}

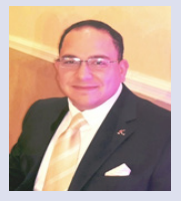

Dr. Karim M. Raafat is an Associate Professor of Phytochemistry and Pharmacognosy at Faculty of Pharmacy, Beirut Arab University. He has completed his PhD from German University in Cairo, New Cairo, Egypt, under the channel system and joint supervision scheme between The German University in Cairo (GUC) and Johann Wolfgang Goethe-University Frankfurt, Germany and postdoctoral studies from Beirut Arab University (BAU) and German University in Cairo. He is a visiting Scientist of Johann Wolfgang Goethe-University, Frankfurt, Germany. He is the Head of Phytochemistry Research Team and Junior Research Team, BAU, Lebanon. He has published more than sixty books, patent, and peer reviewed journal articles and presentations in scientific conferences. He has been honored with several national and international awards in the scientific field and public service.

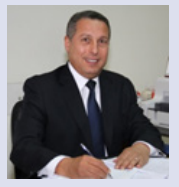

Prof. Abdalla El-Lakany: He is currently the Dean of Faculty of Pharmacy, Beirut Arab University. Dr. El-Lakany has over 25 years of experience in teaching Phytochemistry, Pharmacognosy, and Medicinal Plants, and supervision of PhD, Masters and Pharm.D. theses. He is specialized in chemistry of natural products, with a special interest in diterpenoids, alkaloids and flavonoids. He has attended many national and international conferences and supervising more than 20 Master, Pharm.D and PhD Theses. Currently, he has a research project about alkaloids and their biological testing. He has published more than 55 scientific articles in high-impact journals.

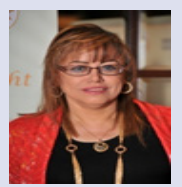

Prof. Maha Aboul-Ela She is the Head of Pharmaceutical Sciences Department, Faculty of Pharmacy, Beirut Arab University. Dr. Aboul-Ela has 30 years experience in teaching (under and post graduates courses) and research in Pharmacognosy and Phytochemistry and 7 years experience in the field of QA in Higher education. Distinguishable Peer Reviewer at Egyptian National Organization for QA and accreditation. She has published more than 50 research articles in national and international scientific journals in the field of specialization. Attending many national and international conferences. Supervising more than 14 Master, Pharm.D and PhD Theses. She had PhD mission to West Germany for completion of practical studies and postdoctoral mission to School of Pharmacy, University of London, UK. She has Membership in the American Society of Pharmacognosy and the Egyptian Pharmaceutical Society.

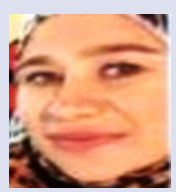

Sara AI Ayoubi is a M.Sc. holder from the Faculty of Pharmacy, Beirut Arab University (BAU) where she graduated in Bachelor of Pharmaceutical Sciences and Master of Pharmacognosy and Medicinal Plants. Her Masters research focused on Phytopharmacological study of Psoralea bituminosa and Trifolium repens L. growing in Lebanon.

Cite this article: Ayoubi SA, Raafat K, El-Lakany A, Aboul-Ela M. Phytochemical Investigation of Psoralea bituminosa L. and its AntiDiabetic Potentials. Pharmacog J. 2018;10(5):841-53. 